\title{
Phytophthora Root Rot: Importance of the Disease, Current and Novel Methods of Control
}

\author{
María L. Giachero ${ }^{1,2}$, Stéphane Declerck ${ }^{3, *}$ and Nathalie Marquez ${ }^{1,2}$ DD \\ 1 Instituto de Patología Vegetal, Centro de Investigaciones Agropecuarias, Instituto Nacional de Tecnología \\ Agropecuaria, Córdoba 5119, Argentina; giachero.lorena@inta.gob.ar (M.L.G.); \\ marquez.nathalie@inta.gob.ar (N.M.) \\ 2 Consejo Nacional de Investigaciones Científicas y Técnicas (CONICET), Unidad de Fitopatología y \\ Modelización Agrícola (UFYMA), Córdoba 5000, Argentina \\ 3 Mycology, Earth and Life Institute, Université catholique de Louvain, 1348 Louvain-la-Neuve, Belgium \\ * Correspondence: stephan.declerck@uclouvain.be
}

Citation: Giachero, M.L.; Declerck, S.; Marquez, N. Phytophthora Root Rot: Importance of the Disease, Current and Novel Methods of Control. Agronomy 2022, 12, 610. https:// doi.org/10.3390/agronomy12030610

Academic Editor: Jadwiga Śliwka

Received: 31 January 2022

Accepted: 26 February 2022

Published: 28 February 2022

Publisher's Note: MDPI stays neutral with regard to jurisdictional claims in published maps and institutional affiliations.

Copyright: (C) 2022 by the authors. Licensee MDPI, Basel, Switzerland. This article is an open access article distributed under the terms and conditions of the Creative Commons Attribution (CC BY) license (https:// creativecommons.org/licenses/by/ $4.0 /)$.

\begin{abstract}
Phytophthora sojae is a pathogen of major agricultural importance, responsible for Phytophthora root rot (PRR) in soybean crops, which can cause significant yield losses each year. The severity of the disease depends on the soybean cultivar, its growth stage at the time of pathogen infection, and the environmental conditions. High soil moisture and temperature around $25-30{ }^{\circ} \mathrm{C}$ are favorable conditions for the development of the disease. Consequently, cultural practices are mainly limited to avoiding bad weather (high moisture) during the sowing or to promoting soil drainage. The use of chemical fungicides is restricted to seed treatments when there is a high risk of disease development. Currently the most economical option for controlling P. sojae is the use of host resistance. However, even if breeding is the main control strategy of PRR, the use of resistant cultivars leads to selection pressure on $P$. sojae populations, which can lead to high variability of the pathogen and therefore to its adaptation to overcome plant resistance. New strategies are therefore needed, including the use of biological control agents (BCAs). The use of BCAs (i.e., microorganisms or their metabolites) is a promising and sustainable alternative to PRR control that should be strengthened. Therefore, this review addresses the $P$. sojae-soybean interaction, mechanisms of pathogenicity and host resistance, as well as current and new management strategies with emphasis on the biological control of $P$. sojae and its associated mechanisms.
\end{abstract}

Keywords: biological control agents; Phytophthora root rot; Phytophthora sojae; soybean

\section{Introduction}

Fungi and oomycetes are the most important soilborne pathogens responsible for several diseases on agronomically important crops, which can lead to severe limitations in production [1]. Within the oomycetes, the genera Phytophthora, Hyaloperonospora, Plasmopara, Pythium, and Albugo are the most devastating, with Phytophthora being by far the genus with the largest number of pathogenic species under study [2], representing one of the biggest threats to global food security. One of the most iconic Phytophthora species is Phytophthora sojae, responsible for root rot in soybean, resulting in billions of dollars in yield losses each year [3]. Several studies have already documented P. sojae pathology, life cycle, host resistance, and disease control strategies [4-6]. In general, chemical control is limited to systemic fungicides and may not be effective due to the pathogen adaptation and the subsequent fungicide tolerance development of the pathogen. Breeding for resistant cultivars therefore remains the main strategy for managing the disease, although this is threatened by the high variability of the pathogen [7]. Novel strategies are therefore required, among which are the use of biological control agents (BCAs), which have become more and more popular for the control of pests and diseases in several crops [8-10]. The use of these alternative biocontrol strategies is in line with the objectives of the 2030 Agenda 
for Sustainable Development adopted by the United Nations in 2015, to support the needs of the present and future generations via sustainable consumption and production (https://sdgs.un.org/2030agenda, accessed on 20 November 2021). Therefore, the aim of this review is to understand the complexity of the P. sojae-soybean interaction, addressing aspects related to the mechanisms of pathogenicity and host resistance and summarizing the current and novel management strategies for the (bio-)control of this major pathogen.

\section{Phytophthora sojae: General Characteristics}

\subsection{The Genus Phytophthora in Brief}

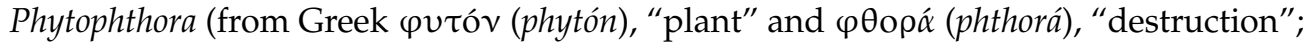
"the plant-destroyer") is a genus that morphologically resemble fungi, but that belong to the Oomycota in the species-rich group of Stramenopiles, constituted by more than 100 species assembled in 10 clades [11,12]. Unlike true fungi, their cell wall contain cellulose instead of chitin, their growth is by means of filamentous hyphae lacking cross-walls and they produce sexual spores called oospores and swimming asexual spores called zoospores. The zoospores are motile by two flagella for locomotion and dispersion under high moisture conditions. Meanwhile, oospores are thick-walled sexual spores produced by homothallic or heterothallic fertilization. Within the genus, there is a diversity between species related to host plants, infected tissues, genome size, etc. [13]. Several members of this genus can cause important plant diseases worldwide, resulting in a complete loss of production. The most iconic example is the Irish potato famine in 1845-1852 by Phytophthora infestans [14]. Other important diseases caused by Phytophthora sp. are tomato late blight (P. infestans), cocoa black pod and papaya blight (P. palmivora), stripe canker on the cinnamon tree and other ornamental and forest trees diseases (P. cinnamomi) and soybean root rot (P. sojae) [15].

\subsection{Phytophthora Root Rot}

Unlike other species of Phytophthora, P. sojae (syn. Phytophthora megasperma f. sp. glycinea) has a narrow host range [16]. Although the lupins (Lupinus), lima bean (Phaseolus lunatus), string bean (Phaseolus vulgaris), and cranesbill (Geranium carolinianum) have also been reported as susceptible hosts [2,16], soybean is the primary host of $P$. sojae [5].

Phytophthora root rot (PRR) is one of the major diseases of soybeans. This monocyclic disease appears after heavy rains under high soil moisture and warm conditions, which are optimal situations for oospore germination. The infection can occur at any stage of soybean growth [5], and according to this, the severity of symptoms can vary markedly. This pathogen principally infects soybean at pre-emergence, being able to cause seed decay and seedling damping-off. When the infection appears at the later stage of growth, the symptoms include root rot, brown stem lesions, leaf yellowing, wilting, and finally, plant death.

The severity of the disease also depends on the level of resistance of the soybean cultivar that can vary from partial resistance to root resistance and R-gene mediated resistance [17]. The first two types of resistance are quantitatively inherited as a multigenic trait, whereby several genes contribute to the level of resistance; while the R-gene mediated resistance is a race specific resistance that is qualitatively inherited. In highly susceptible soybean cultivars, $P$. sojae colonize roots and stems, becoming chocolate brown. The leaves turn yellow and wilt. In these cultivars, practically every single plant in the field may be killed. As partial resistance increases, the damage caused by the disease decreases. Thus, the losses generated in cultivars with moderate to low partial resistance generally do not exceed $50 \%$, while in cultivars with higher partial resistance, the roots are infected but do not develop stem rot. In these cases, the roots are light brown in color. Cultivars with high levels of partial resistance carry no visible symptoms and show a reduced yield loss. The specific resistance that gives R-genes generally is a complete resistance, since it is conditioned by single dominant Rps genes. However, this type of resistance is not effective for all populations of $P$. sojae given that it varies according to the geographical regions [5]. 


\subsection{Phytophthora sojae Life Cycle}

P. sojae forms two types of spores: oospores and zoospores. The oospores are sexual thick-walled cells that can germinate into hyphae under high soil moisture conditions (generally in compacted soil) and temperature around $25-30^{\circ} \mathrm{C}$. From these hyphae, two types of asexual cells can be formed: zoosporangia and zoospores [18]. Zoosporangia give rise to zoospores that can germinate and infect the host tissues directly. Zoospores have two flagella that allow them to swim for several hours. It has been observed that the severity of the disease correlates with the amount of water in the soil, suggesting that zoospores are the principal source of propagation of this pathogen. Zoospores move towards the root by recognizing chemical signals (i.e., isoflavones) of the host. Once they find the surface of the root, they adhere as a cyst and penetrate the cell through a germ tube, giving rise to the infection. This chemotactic attraction is highly specific to soybean-P. sojae interaction because P. sojae is attracted by isoflavones (daidzein and genistein) that are released by soybean plants $[19,20]$. These isoflavones are present in the seeds and root exudates of soybean. Since other Phytophthora species do not show the same attraction for these compounds, it has been suggested that the sensitive attraction of $P$. sojae zoospores to these isoflavones may be the main mechanism that determines host range [19]. During compatible interaction, $P$ sojae colonizes the root and stem tissues giving rise to characteristic symptoms of Phytophthora root rot. The oospores are produced in large numbers in infected plant tissue under unfavorable conditions (low humidity and temperature). These sexual spores can survive for a long time in the soil and plant debris, awaiting favorable conditions for germination and the initiation of a new disease cycle.

\subsection{Phytophthora sojae Variability}

P. sojae draft genome sequence was first published by Tyler et al. (2006) [13]. The final assembly contained $79.3 \mathrm{Mb}$ and 26,584 predicted genes. This genome has a bipartite organization, with conserved and highly dynamic regions $[4,13,21]$. Later, the P. sojae genome project was completed by using modern sequencing tools that revealed genomic variations [22]

The first report of the pathogenic variability of $P$. sojae was observed in Illinois in 1955 [23]. Since then, the disease was reported in all soybean-producing regions [24]. Recently, a variability in the number of pathotypes of $P$. sojae was observed in different soybean areas (e.g., Canada, USA, Argentina), indicating that the complexity of this pathogen has increased in this population $[7,25]$. Although the use of soybean cultivars with single dominant resistance genes to $P$. sojae (Rps) has allowed them to control the disease for years, the massive deployment of Rps genes in soybean has caused a rapid evolution of the virulence of $P$. sojae. Fields with years of soybean cultivation show a greater diversity of pathotypes than fields where soybean cultivation is recent. New pathotypes of the pathogen continuously appear worldwide. Thus, $P$. sojae is considered a highly variable pathogen [26]. Currently, at least 200 pathotypes of the pathogen have been reported [27]. It is important to know the complexity of $P$. sojae pathotypes found in each soybean region as this allows for better decision-making regarding which Rps-resistant soybean genotype to use to avoid PRR losses.

The pathogenic variants of $P$. sojae are evaluated according to the response to soybean cultivars with different Rps. There are more than 33 Rps genes/alleles located on nine soybean chromosomes (chromosomes 2, 3, 7, 10, 13, 16, 17, and 18) that confer specific resistance for each race of P. sojae [28]. Among them, Rps1 (alleles Rps1a, Rps1b, Rps1c, Rps1d, Rps1k), Rps2, Rps3 (alleles Rps3a, Rps3b, Rps3c), Rps4, Rps5, Rps6, Rps7, Rps8, Rps9, RpsSu, Rps10 [29], Rps11, Rps12, RpsZS18, RpsYu25, RpsHN, RpsQ, RpsX, RpsYD29 [30], RpsWY, RpsHC18 [31], RpsSN10, RpsUN1, RpsUN2, RpsJS, RpsYB30, RpsZS18, and RpsSu have been identified and mapped [32-42]. 


\subsection{Phytophthora sojae Pathogenicity}

Many studies have focused their attention on characterizing and comparing the diversity of $P$. sojae pathotypes to predict which Rps genes are the most effective for breeding programs [43-45]. Furthermore, specific and global transcriptional studies of $P$. sojae have been carried out to identify genes involved in pathogenesis [46,47], in particular genes coding for effectors that interfere with the soybean immune system [48-50]. The knowledge about $P$. sojae secreted effectors is vast [51]. Some of these effectors act outside (apoplastic) and others inside the host cells (cytoplasmic) to suppress soybean immunity, favoring pathogen development. Among them, the P. sojae genome contains several necrosis- and ethylene-inducing-like proteins (NLP), genes, and pseudogenes. NLPs are conserved apoplastic effectors widely distributed in eukaryotic and prokaryotic plant pathogens. It is known that the majority of $P$. sojae NLPs do not cause visible necrotic symptoms in plant tissues and are supposed to have various functional roles [52]. Another apoplastic effector with hydrolytic activity toward xyloglucan, xyloglucan-specific endoglucanase 1 (PsXEG1) has been reported to be highly expressed during the first steps of infection [53]. Even though this effector can be blocked by a soybean glucanase inhibitor protein (GmGIP1), P. sojae can protect PsXEG1 by a paralogous known as PsXLP1. This "pseudo-effector" has no enzyme activity but has higher binding affinity to GmGIP1, thus freeing the PsXEG1 [54].

Most of the cytoplasmic effectors are RxLR, and thus have two conserved N-terminal motifs (RxLR and dEER) for entry into host cells. These proteins with RXLR or dEER motifs are recognized by $R$ genes in a gene-for-gene manner in the cytoplasm of the host plant and can eventually manipulate its defense in favor of infection, and even suppress plant programmed cell death (PCD). Another class of cytoplasmic effectors with a conserved motif, FLAK (F, Phe; L, Leu; A, Ala; and K, Lys), are Crinklers (CRNs). For example, P. sojae CRN78 acts suppressing host immune signaling by targeting phosphorylation and degradation of plant aquaporin proteins [55]. Other CRN effectors can reprogram host gene expression by targeting their promoters [56]. In addition, data suggest that $P$. sojae secretes effectors with opposite functions in the host cell death modulation that are jointly required for full virulence [48]. Finally, there is a cytoplasmic effector with the non-classical signal peptide (i.e., PsISC) that can reprogram the host salicylate metabolism pathway by hydrolyzing its precursor [57]. Interestingly, a protocol for implementing the CRISPR/Cas9 technology in P. sojae has been developed [58]. This novel tool allows to create heritable genome modification and deepen our understanding of $P$. sojae pathogenesis for cultivar breeding and other disease control strategies as well. Recently, the use of this gene editing technology has elucidated the biological functions of a P. sojae glycosyl hydrolase (PsGRGH). Results showed that PsGRGH was associated with the mycelial morphology, sporangium development, and virulence of P. sojae. Additionally, this protein seems to be essential for tolerance to biological control strains (Bacillus) and abiotic stresses [59].

\subsection{Molecular Response of Soybean to Phytophthora sojae}

During the Soybean-P. sojae recognition stage, root exudates (i.e., the isoflavones daidzein and genistein) attract the pathogen zoospores and stimulate the encystment and germination [19]. Following infection, the soybean transcriptome is remodeled and its response differs according to genotypic differences and Phytophthora infection (Figure 1) [60]. During susceptible interactions, soybean induces a wide array of biological processes after $P$. sojae infection, including up-regulation of the jasmonic acid (JA) pathway, suppression of ethylene (ET) pathway, and no significant changes in salicylic acid (SA) and brassinosteroids (BR) pathways [61]. Gene expression analysis reflects changes during the infection progress. During the initial biotrophic phase, few changes are detectable, and they mainly concern phytoalexin metabolism and the induction of defense and signaling proteins (e.g., protein kinase, peroxidase, calmodulin). Meanwhile, $24 \mathrm{~h}$ post-infection, a high number of expression changes are observed and coincide with the pathogen necrotrophic phase transition. During the P. sojae necrotrophic phase, soybean transcriptome shows a set of down-regulated genes (e.g., lipoxygenases and peroxidases) and a strong induction 
of glycolysis and citric acid and glyoxylate cycle and phytoalexin biosynthesis related genes [62]. In addition, microRNAs associated with $P$. sojae infection have been characterized. Among them miR1507, miR1508, miR1510, miR159, miR319, miR396, and miR482 families were negatively regulated, whereas families of miR156, miR166, and miR171 were positively regulated. The potential targets of these microRNAs are defense-related kinase and transcriptional factors [63].

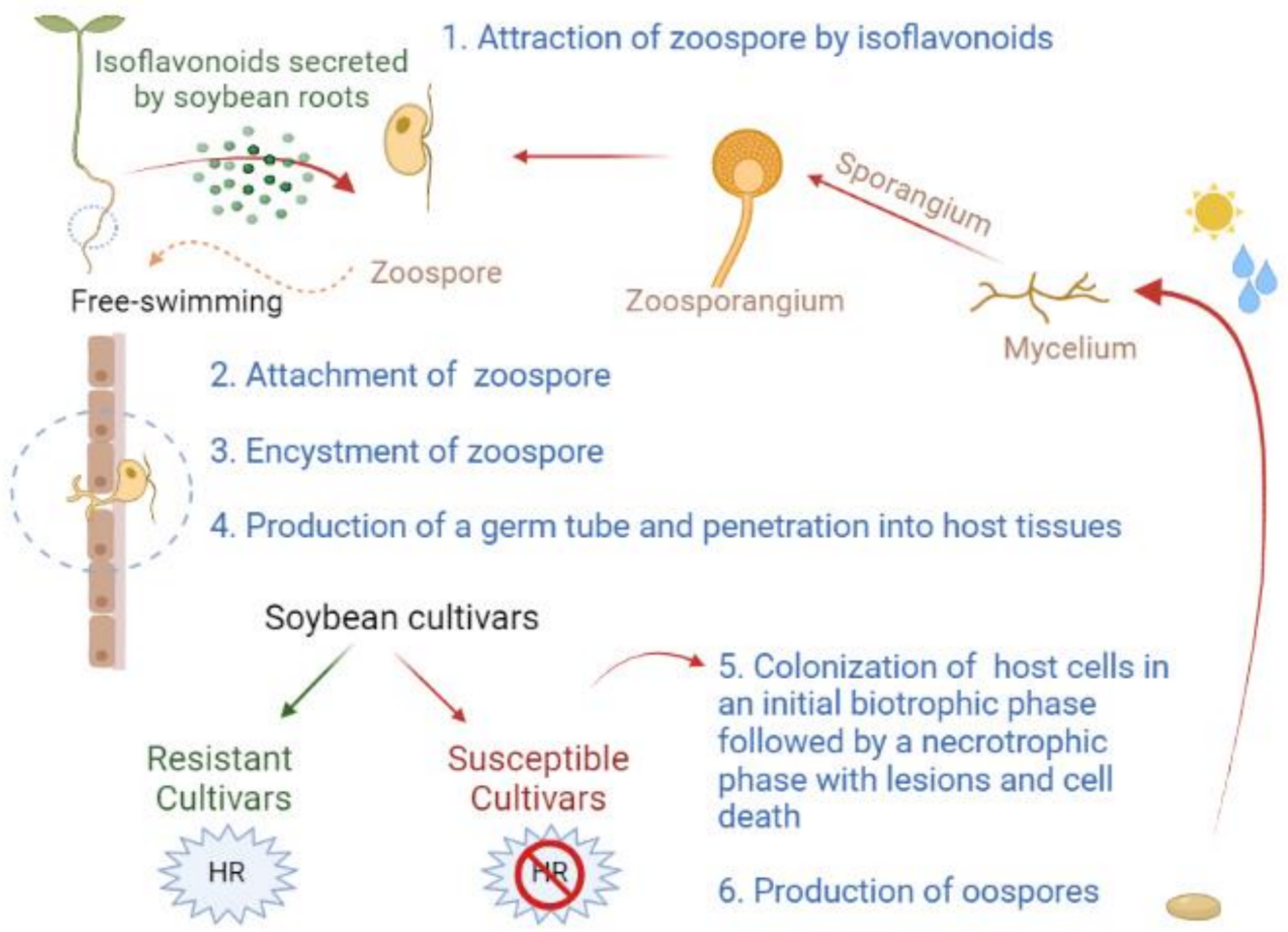

Figure 1. Process of P. sojae infection and response of soybean according to susceptible and resistant cultivars. The zoospores are attracted by root exudates (isoflavones daidzein and genistein), attach to the root surface and encyst before producing a germination tube entering the plant cells. If the host is a resistant cultivar, it induces hypersensitive reaction giving an incompatible interaction. Conversely, if the host is a susceptible cultivar, it triggers a wide array of biological processes following infection. The pathogen colonizes host cells in an initial biotrophic phase followed by a necrotrophic phase with necrotrophic lesions resulting in host cells death. Finally, under unfavorable conditions (low humidity and temperature) oospores are produced. These sexual spore can survive for a long time in the soil and plant debris. They can germinate and initiate a new disease cycle if the conditions are favorable for the disease development (high moisture and temperature around $25-30^{\circ} \mathrm{C}$ ).

Transcriptomic studies in resistant cultivars showed the up-regulation of cDNAs encoding enzymes of phytoalexin biosynthesis and pathogenesis-related proteins (Pru ar 1 gene belonging to PR-10 family) potentially involved in resistance to PRR [64]. In addition, Narayanan et al. (2009) [65] identified signaling genes (up and down-regulated) in the incompatible interaction. Among them are the down-regulation of genes encoding regulators of the chromosome condensation (RCC1) family protein. Even though it is known that PRR incompatibility is controlled by Rps (Resistance to P. sojae) genes, and there are huge variations in the molecular response between soybean near isogenic lines (NILs). It seems Rps genes/alleles have distinct timing and robustness in defense signaling [61].

Interestingly, several soybean genes, e.g., those encoding for pathogenesis-related protein (GmPR10), dirigent protein (GmDRR1), isoflavone reductase (GmIFR), a novel pathogenesis-related protein (GmPRP), chalcone Isomerase (GmCHI), and WRKY transcription factors (GmWRKY31, GmWRKY40), have been reported to play an important role in soybean resistance to $P$. sojae [66-72]. 
Furthermore, proteomic studies provided additional information about soybean defense against $P$. sojae. In fact, it has been proposed that the main mechanism during incompatible interaction is a local response with a $\mathrm{H}_{2} \mathrm{O}_{2}$ accumulation, the induction of salicylic acid (SA) signal pathway and the biosynthesis of high levels of isoflavones [73]. Moreover, elevated levels of ascorbate peroxidase suggested their potential role in reactive oxygen species (ROS) scavenging for the cellular homeostasis maintenance [74].

Other studies, using proteomic approaches, have focused on the exogenous application of BRs and their capacity to mediate response to P. sojae in soybean. BRs significantly enriched the lignin biosynthesis, which was consistent with the resistance phenotype [75].

Particular metabolites, such as the auxin IAA (indole-3-acetic acid), increase in susceptible soybean roots in the presence of the pathogen. Indeed, better modulation of auxin levels is associated with resistance to PRR [76]. Moreover, transcriptional and metabolic studies allowed the identification of groups of metabolites potentially involved in resistance to PRR (i.e., sugars, organic acids, amino acid derivatives and secondary metabolites). However, only a few differentially expressed genes, such as those encoding invertases, chalcone synthases, 2-hydroxyisoflavanone synthases, and xanthine dehydrogenase/oxidase, were involved in the regulation of potential resistant substances [77]. The integration of these transcriptomic and metabolomic data illustrates the limitation of the omics application separately, since some modifications in the transcriptome do not necessarily have an absolute correlation downstream.

\section{Control Strategies of Phytophthora Root Rot}

Currently, control of soybean PRR include the use of resistant cultivars, soil drainage, and seed treatment with fungicides [5]. Although these strategies are widely used and effective in limiting crop productivity losses, their intensive use can produce potential negative effects that must be taken into account. In recent years, the use of biocontrol strategies has grown substantially as a promising alternative to reduce pathogen resistance or environmental pollution. Among them, the use of microorganisms or their metabolites as well as plant extracts, minerals, and ions are considered in disease management programs $[78,79]$.

\subsection{Host Resistance}

The most economical option for controlling $P$. sojae is the use of resistant soybean cultivars [80]. Backcross (BC) breeding is the most commonly used method for the secure production of plant resistance. This methodology consists in crossing an agronomically adapted genotype (GA) with another genotype carrying a gene of interest (e.g., resistance gene). The resulting progeny is then crossed with the GA for several generations, selecting at each cycle of $\mathrm{BC}$ breeding the gene of interest [81]. The complete genome sequence of the soybean [82] has allowed genetic breeding programs to select genes of interest through genetic markers. The most commonly used molecular markers (MM) for gene mapping and assisted selection are simple sequence repeat (SSRs), sequence characterized amplified region (SCAR), and sequence tagged site (STS). These markers are easily reproduced in laboratory via the use of the polymerase chain reaction (PCR). Although these MM are still used in classic genetic breeding programs, the new technologies of massive DNA sequencing (next-generation sequencing NGS) have become the main strategy for the discovery of single nucleotide polymorphisms (SNPs) and genotyping in large populations. Among the used methods are the restriction site-associated DNA tag sequencing (RADseq), genotyping by-sequencing (GBS), $2 \mathrm{~b}-\mathrm{RAD}$, and specific length amplified fragment sequencing (SLAF-seq) [75].

Currently, there are more than 33 Rps genes reported in soybean, several of which are commercially used to protect plants against $P$. sojae. The gene Rps1 encoding six alleles is the most widely used in breeding programs as a source of resistance to P. sojae, particularly Rps1k [83]. However, the utilization of resistant cultivars causes a selection pressure over $P$. sojae populations that may lead to Rps gene adaptation, consequently requiring the 
development of alternative control strategies. The capability of the pathogen to overcome the plant resistance depends on its capacity to suppress or alter the initial stage of the plant-pathogen interaction (recognition stage), allowing its growth and reproduction. This virulence gain can be accomplished by several mechanisms. The pathogen avirulence genes $(A v r)$ are located in repetitive regions of the genome, where mutation or recombination events are more likely to occur, leading to modifications or complete losses of these genes. Moreover, the pathogen can acquire an additional epistatic effector that suppresses the immune response. In fact, avirulent genes could be regulated at the transcriptional level, as the result of a mutation in the regulatory regions or by the differential expression of sequence-identical epialleles [84].

\subsection{Chemical Control}

Chemical pesticides, from fungicides to algaecides, have been used for oomycetes control with varying degrees of success $[85,86]$. The efficacy of chemical formulations is associated to their mode of action, their persistence, and the biology of the target pathogen. Particularly, the chemical control of underground pathogens is restricted to the use of systemic fungicides that are absorbed by the plant. Among them, the use of metalaxylbased formulations is used to control P. sojae [87]. Seed treatment with this substance has been shown to be beneficial when there is a high risk of disease development $[88,89]$. However, the flexibility of $P$. sojae to adapt and overcome chemical control methods and the increasing public concern on the intensive use of agrochemicals demand the consideration of more sustainable alternatives (as nano-fungicides or bio-pesticides) to ensure the success of environment protection and food safety.

\subsection{Agronomic Practices}

PRR control through cultural practices is mainly limited to avoiding bad weather (high moisture) during the sowing or through soil drainage [5]. No-tillage, which has shown many advantages for agricultural systems [90], can lead to PRR development since the presence of a higher level of $P$. sojae inoculum has been observed during this practice as compared to conventional tillage [91]. Similarly, fertilization with potassium chloride can potentially increase the incidence of PRR on soybean seedlings [92]. Crop rotation is not an effective option due to the ability of oospores to survive for long periods in the soil. However, it has been shown that it can contribute to maintaining a uniform diversity, in order to avoid a dominant race that leads to the loss of resistance of cultivars [93]. Interestingly, intercropping between soybean and maize could suppress $P$. sojae disease. Phenolic acids in maize rhizosphere have strong antimicrobial activity and interfere with zoospores chemotaxis [94]. Nevertheless, this practice requires attention, since during interspecies interactions, non-host roots can recruit many microbial species, which can be beneficial or harmful to the crop of interest.

\subsection{Integrated Disease Management (IDM)}

This disease management system consists in the combination, according their compatibility, of all suitable techniques and methods available in order to maintain the pathogen population at levels below those causing economic injury [95]. In the case of $P$. sojae, this approach may consist in combining some of the strategies presented above to increase the type of resistance (quantitative or qualitative) with the use of fungicides and agricultural practices.

\subsection{Biological Control Agents (BCAs)}

Soil contains a huge reservoir of microorganisms that comprise bacteria $\left(4-20 \times 10^{9}\right.$ cells $\left.\mathrm{cm}^{-3}\right)$, protists $\left(10^{4}-10^{7}\right.$ cells $\left.\mathrm{m}^{-2}\right)$, fungi $\left(10^{6}-10^{9}\right.$ cells $\left.^{-1}\right)$, and viruses (up to $10^{9} \mathrm{~g}^{-1}$ soil) with millions of species or ecotypes [96]. Within the plant rhizosphere, many of these microorganisms or even the metabolites that they produce can be used for biocontrol. In fact, most BCAs have been isolated from the rhizosphere or plant tissues, 
since a large number of them are endophytic. Very recently, Bolivar-Anillo et al. (2020) [83] summarized all the studies in which endophytic bacteria and fungi had been used successfully against different species of Phytophthora. However, studies based on the use of BCAs to control PRR are few (see Figure 2).

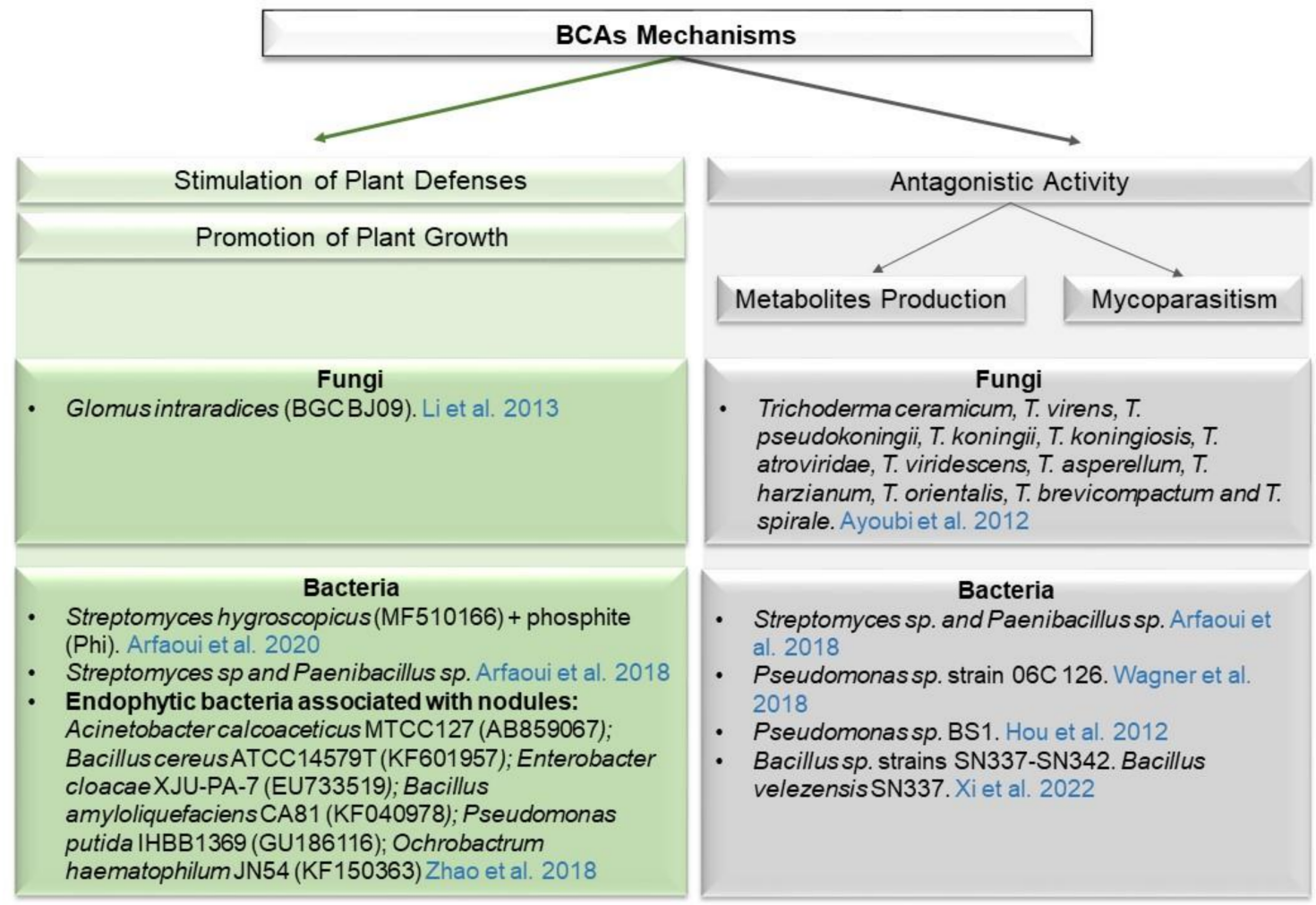

Figure 2. Biocontrol agents for the management of the Phytophthora root rot and the associated mechanisms. In green are BCAs (fungi and bacteria) associated to the promotion of plant growth and stimulation of plant defense. In grey are BCAs (fungi and bacteria) with antagonistic activity.

The most often reported mechanisms used by BCAs to protect the plant from pathogens include: competition for infection sites, competition for substrate, antibiosis, production of siderophores, mycoparasitism, production of cell wall degrading enzymes, and the induction of the plant immune resistance. In most of the cases, more than one of these mechanisms can act simultaneously [97]. However, the ability of the BCAs to control pathogens depends on various factors, such as their capacity to interact with the plants, the pathogen itself, the soil microbiome, and many other 'agro'-environmental factors.

\subsubsection{Promotion of Plant Growth}

A variety of bacteria and fungi isolated from the rhizosphere can improve plant growth through biological nitrogen fixation, mineral solubilization ( $\mathrm{P}$ and $\mathrm{Zn}$ ), and phytohormone production, at the same time resulting in plants more resistant to pathogens [98]. Bacteria belonging to Paenibacillus, Bacillus, and Streptomyces isolated from the soil (rhizoplane and rhizosphere) have shown antagonist activity against $P$. sojae. In particular, one strain of Streptomyces hygroscopicus S11 was reported to reduce by 50\% the disease severity caused by $P$. sojae and to improve soybean shoot and root weight through auxin production, nitrogen fixation, and siderophore production [99]. Interestingly, the separate application of S. hygroscopicus S11 and potassium phosphite (Phi) solution reduced soybean root rot symptoms, and a synergic effect in the soybean plant growth was observed when both treatments were combined [100]. 


\subsubsection{Stimulation of Plant Defenses}

Plants are able to recognize the presence of microorganisms through pattern recognition receptors, and in consequence induce their defense. The recognition of pathogenassociated molecular patterns, PAMPs, or microbe-associated molecular patterns, MAMPs (i.e., non-pathogenic microorganism), triggers a cascade of cellular signals with a defense gene activation (antimicrobial compounds, resistant protein, phenolic compounds). Several beneficial microorganisms activate plant immunity via induced systemic resistance (ISR).

Arbuscular mycorrhizal fungi (AMF) and Trichoderma are the fungi most widely used for improving plant resistance to diseases. It has been shown that the use of AMF improves the resistance of host plants against different pathogens (virus, fungi, bacteria, nematodes), possibly because of better plant nutrition and the activation of the mycorrhizal induce resistance (MIR) [101]. Recent studies have shown that mycorrhizal soybean plantlets had a reduction in soilborne pathogen colonization and an important transcriptional reprogramming [102-104], suggesting an AMF regulation of the host defense response. Although mycorrhizal protection has been extensively studied, there are only a few studies that have demonstrated soybean protection against $P$. sojae. AMF enhanced the resistance of soybean plants against $P$. sojae through the release of $\mathrm{H}_{2} \mathrm{O}_{2}$ and jasmonic acid accumulation in response to infection [105]. Arfaoui et al. (2020) [100] tested the combined effect of S. hygroscopicus and phosphite (Phi) in susceptible and tolerant soybean cultivars. The effect of pre-treatment (S. hygroscopicus + Phi) was observed on defense responses and salicylic acid (SA) and jasmonic acid (JA) production. The susceptible cultivars showed higher levels of SA and JA than the tolerant cultivars after P. sojae infection. Soybean plants pre-treatment (S. hygroscopicus + Phi) showed a reduction of the level of SA and JA in response to $P$. sojae. The differential accumulation of these hormones in the time suggests a regulation of interaction by the temporal coordination of defense-related genes.

\subsubsection{Antagonistic Activity}

Many microbial species have been reported for their antagonistic activity, including Trichoderma, Bacillus, and Pseudomonas [78]. In general, antagonistic microorganisms have no unique mode of action. Some of them include metabolite production, mycoparasitism, antibiosis, and competition. Arfaoui et al. (2018) [99] isolated rhizospheric bacteria adhering to soybean roots and evaluated in vitro and under greenhouse conditions their potential biocontrol activity. Six isolates were efficient against $P$. sojae race 4 under in vitro conditions, while only two isolates belonging to the genera Paenibacillus and Streptomyces, had potential biocontrol properties for PRR. These observations are in agreement with numerous studies that have demonstrated the biocontrol potentials of bacteria and fungi against important phytopathogenic fungi [106,107].

A combined study involving antagonistic assays and whole genome analysis predicted that Pseudomonas isolated from aquatic ecosystems can produce a non-ribosomal peptide synthetase (NRPS) and two bacteriocin with the ability to inhibit oomycetes. Furthermore, authors identified 21 biosynthetic gene clusters with potential for antagonistic activity, suggesting that more than one inhibitory compound can be produced under different environmental conditions [108]. Pseudomonas capacity to produce compounds with potential for biological control has also been studied. For instance, Bi et al. (2012) [109] reported that Pseudomonas sp. BS1 produces rhamnolipids, metabolites obtained from fermentation filtrates, which have effects on the normal growth and development of the hyphal, zoosporangium, and zoospore of $P$. sojae.

Several endophytic bacteria associated with nitrogen-fixing nodules, including Acinetobacter, Bacillus, Enterobacter, Ochrobactrum, and Pseudomonas, can exert antagonistic activity against $P$. sojae through siderophores and lytic enzymes (chitinase and laminarinase) production [110].

The Trichoderma genus contains several antagonistic species that have been widely studied and commercially used due to their capacity to protect the plant and reduce the pathogen populations [111]. Ayoubi et al. (2012) [112] found that Bradyrhizobium 
and Trichoderma dual inoculation could control P. sojae and promote the growth of soybean plants. Furthermore, different Trichoderma species isolated from fields in Iran in combination with commercial B. japonicum were tested for their biocontrol effects in soybean against P. sojae. Even though all the species of Trichoderma tested in this work reduced the pathogen growth by mycoparasitism and by the production of volatile and non-volatile metabolites, T. brevicompactum was the most effective against $P$. sojae and was proposed to be used in the management of PRR. Importantly, although all these studies were able to demonstrate biological control of $P$. sojae, there are only few works that evaluated the impact of BCAs in the field. Recently, Xi et al. (2022) [113] studied the specific effects of six bacteria selected from soybean rhizosphere in China. All the tested strains showed antagonistic activity against $P$. sojae. However, one of these strains, identified as Bacillus velezensis (SN337), was the most promising. Results suggested a reduction of severity in root rot incidence that could be explained by the antagonist effect of Bacillus SN337 over P. sojae, and by the improvement of the bacterial community structure in the soybean rhizosphere.

\section{Concluding Remarks and Future Perspectives}

One of the major concerns about PRR is the increasing variability of P. sojae, since genetic resistance mediated by Rps genes is the major mechanism of disease control. However, many other factors can influence the virulence activity of the pathogen [114]. Particularly, knowledge about how environmental conditions affect the pathogen fitness during its life cycle can help to integrate concepts for more efficient disease control. As was shown in this review, a diversity of microorganisms that coexist within the host or in the rhizosphere can increase or decrease the disease severity caused by Phytophthora species including P. sojae. Nevertheless, only a few studies have considered the use of BCAs as a sustainable management strategy of PRR. If the potential of these BCAs is thus undeniable, their effects can vary according to multiple factors, which makes them vulnerable to impractical use by the agricultural world compared to chemical pesticides. Moreover, it is important to remember that BCAs can enter into competition with established microbial communities and can spread to other cultures. Their safety for human/animal health must also be established before their use in agricultural systems. Therefore, in this review, we highlighted the need to study in detail how the application of BCAs can affect the pathogen and the rhizosphere microbiota, and if soil community modification can influence the plant-BCA interaction. In this sense, the challenge is the development of research with a combination of techniques that will allow to study the overall effect of the use of BCAs on the pathogen growth, disease development, and the environment. Knowledge about how these microorganisms behave in situ may allow human or environmental risk assessment. We are convinced that the combination of current management practices and the application of BCAs represents a promising approach for successful crop protection.

Author Contributions: Conceptualization, M.L.G., N.M. and S.D.; writing-original draft preparation, M.L.G. and N.M.; writing-review and editing, M.L.G., N.M. and S.D.; performed the figures, M.L.G.; supervision S.D.; funding acquisition, S.D. All authors have read and agreed to the published version of the manuscript.

Funding: This research received no external funding.

Data Availability Statement: This is not applicable since it is a review paper.

Conflicts of Interest: The authors declare no conflict of interest.

\section{References}

1. Bebber, D.P.; Gurr, S.J. Crop-Destroying Fungal and Oomycete Pathogens Challenge Food Security. Fungal Genet. Biol. 2015, 74, 62-64. [CrossRef] [PubMed]

2. Kamoun, S.; Furzer, O.; Jones, J.D.G.; Judelson, H.S.; Ali, G.S.; Dalio, R.J.D.; Roy, S.G.; Schena, L.; Zambounis, A.; Panabières, F.; et al. The Top 10 Oomycete Pathogens in Molecular Plant Pathology. Mol. Plant Pathol. 2015, 16, 413-434. [CrossRef] [PubMed]

3. Wrather, A.; Shannon, G.; Balardin, R.; Carregal, L.; Escobar, R.; Gupta, G.K.; Ma, Z.; Morel, W.; Ploper, D.; Tenuta, A. Effect of Diseases on Soybean Yield in the Top Eight Producing Countries in 2006. Plant Health Prog. 2010, 11, 29. [CrossRef] 
4. Tyler, B.M. Phytophthora sojae: Root Rot Pathogen of Soybean and Model Oomycete. Mol. Plant Pathol. 2007, 8, 1-8. [CrossRef] [PubMed]

5. Dorrance, A.E. Management of Phytophthora sojae of Soybean: A Review and Future Perspectives. Can. J. Plant Pathol. 2018, 40, 210-219. [CrossRef]

6. Dorrance, A.E.; Berry, S.A.; Anderson, T.R.; Meharg, C. Isolation, Storage, Pathotype Characterization, and Evaluation of Resistance for Phytophthora sojae in Soybean. Plant Health Prog. 2008, 9, 35. [CrossRef]

7. Tremblay, V.; McLaren, D.L.; Kim, Y.M.; Strelkov, S.; Conner, R.; Wally, O.; Bélanger, R.R. Molecular Assessment of Pathotype Diversity of Phytophthora sojae in Canada Highlights Declining Sources of Resistance in Soybean. Plant Dis. 2021, 105, $4006-4013$. [CrossRef] [PubMed]

8. Marquez, N.; Giachero, M.L.; Declerck, S.; Ducasse, D.A. Macrophomina phaseolina: General Characteristics of Pathogenicity and Methods of Control. Front. Plant Sci. 2021, 12, 634397. [CrossRef]

9. Smolińska, U.; Kowalska, B. Biological Control of the Soil-Borne Fungal Pathogen Sclerotinia sclerotiorum-A Review. J. Plant Pathol. 2018, 100, 1-12. [CrossRef]

10. Niu, B.; Wang, W.; Yuan, Z.; Sederoff, R.R.; Sederoff, H.; Chiang, V.L.; Borriss, R. Microbial Interactions Within Multiple-Strain Biological Control Agents Impact Soil-Borne Plant Disease. Front. Microbiol. 2020, 11, 2452. [CrossRef]

11. Kroon, L.P.N.M.; Brouwer, H.; De Cock, A.W.A.M.; Govers, F. The Genus Phytophthora Anno 2012. Phytopathology 2012, 102, 348-364. [CrossRef] [PubMed]

12. Martin, F.N.; Gloria Abad, Z.; Balci, Y.; Ivors, K. Identification and Detection of Phytophthora: Reviewing Our Progress, Identifying Our Needs. Plant Dis. 2012, 96, 1080-1103. [CrossRef]

13. Tyler, B.M.; Gijzen, M. The Phytophthora sojae Genome Sequence: Foundation for a Revolution. In Genomics of Plant-Associated Fungi and Oomycetes: Dicot Pathogens; Springer-Verlag: Berlin/Heidelberg, Germany, 2014; pp. 133-157. [CrossRef]

14. Fry, W. Phytophthora Infestans: The Plant (and R Gene) Destroyer. Mol. Plant Pathol. 2008, 9, 385-402. [CrossRef]

15. Hansen, E.M.; Reeser, P.W.; Sutton, W. Phytophthora beyond Agriculture. Annu. Rev. Phytopathol. 2012, 50, 359-378. [CrossRef] [PubMed]

16. Erwin, D.C.; Ribeiro, O.K. Phytophthora Diseases Worldwide; American Phytopathological Society Press: St. Paul, MN, USA, 1996.

17. Dorrance, A.E.; Mills, D.; Robertson, A.E.; Draper, M.A.; Giesler, L. Phytophthora Root and Stem Rot of Soybean. Plant Health Instr. 2007. [CrossRef]

18. Chen, X.; Wang, Y. Phytophthora sojae. In Biological Invasions and Its Management in China; Springer: Singapore, 2017; pp. 199-223. [CrossRef]

19. Morris, P.F.; Ward, E.W.B. Chemoattraction of Zoospores of the Soybean Pathogen, Phytophthora sojae, by Isoflavones. Physiol. Mol. Plant Pathol. 1992, 40, 17-22. [CrossRef]

20. Tyler, B.M.; Wu, M.H.; Wang, J.O.M.; Cheung, W.; Morris, A.P.F. Chemotactic Preferences and Strain Variation in the Response of Phytophthora sojae Zoospores to Host Isoflavones. Appl. Environ. Microbiol. 1996, 62, 2811-2817. [CrossRef] [PubMed]

21. Anderson, R.G.; Deb, D.; Fedkenheuer, K.; McDowell, J.M. Recent Progress in RXLR Effector Research. Mol. Plant-Microbe Interact. 2015, 28, 1063-1072. [CrossRef] [PubMed]

22. Zhang, X.; Liu, B.; Zou, F.; Shen, D.; Yin, Z.; Wang, R.; He, F.; Wang, Y.; Tyler, B.M.; Fan, W.; et al. Whole Genome Re-Sequencing Reveals Natural Variation and Adaptive Evolution of Phytophthora sojae. Front. Microbiol. 2019, 10, 2792. [CrossRef]

23. Kaufmann, J. Root and Stem Rot Od Foybean Caused by Phytophthora sojae N. Sp. Ph.D. Thesis, Univerity of Illions, Chicago, IL, USA, 1957.

24. Hartman, G.L.; Bowen, C.R.; Haudenshield, J.S.; Fox, C.M.; Cary, T.R.; Diers, B.W. Evaluation of Disease and Pest Damage on Soybean Cultivars Released from 1923 through 2008 under Field Conditions in Central Illinois. Agron. J. 2015, 107, 2373-2380. [CrossRef]

25. Grijalba, P.E.; Ridao, A.D.C.; Guillin, E.; Steciow, M. Pathogenic Diversity of Phytophthora sojae in the Southeast of the Province of Buenos Aires. Trop. Plant Pathol. 2020, 45, 397-401. [CrossRef]

26. Schmitthenner, A.F. Problems and Progress in Control of Phytophthora Root Rot of Soybean. Plant Dis. 1985, 69, 362-368. [CrossRef]

27. Dorrance, A.E.; Kurle, J.; Robertson, A.E.; Bradley, C.A.; Giesler, L.; Wise, K.; Bradley, C.A. Pathotype Diversity of Phytophthora sojae in Eleven States in the United States. Plant Dis. 2016, 100, 1429-1437. [CrossRef]

28. Jiang, B.; Cheng, Y.; Cai, Z.; Li, M.; Jiang, Z.; Ma, R.; Yuan, Y.; Xia, Q.; Nian, H. Fine Mapping of a Phytophthora-Resistancelocus RpsGZ in Soybean Using Genotyping-by-Sequencing. BMC Genom. 2020, 21, 1-11. [CrossRef]

29. Zhang, J.; Xia, C.; Duan, C.; Sun, S.; Wang, X. Identification and Candidate Gene Analysis of a Novel Phytophthora Resistance Gene Rps10 in a Chinese Soybean Cultivar. PLoS ONE 2013, 8, e69799. [CrossRef]

30. Zhang, J.; Xia, C.; Wang, X.; Duan, C.; Sun, S.; Wu, X.; Zhu, Z. Genetic Characterization and Fine Mapping of the Novel Phytophthora Resistance Gene in a Chinese Soybean Cultivar. Theor. Appl. Genet. 2013, 126, 1555-1561. [CrossRef]

31. Zhong, C.; Sun, S.; Li, Y.; Duan, C.; Zhu, Z. Next-Generation Sequencing to Identify Candidate Genes and Develop Diagnostic Markers for a Novel Phytophthora Resistance Gene, RpsHC18, in Soybean. Theor. Appl. Genet. 2018, 131, 525-538. [CrossRef]

32. Cheng, Y.; Ma, Q.; Ren, H.; Xia, Q.; Song, E.; Tan, Z.; Li, S.; Zhang, G.; Nian, H. Fine Mapping of a Phytophthora-Resistance Gene RpsWY in Soybean (Glycine max L.) by High-Throughput Genome-Wide Sequencing. Theor. Appl. Genet. 2017, 130, $1041-1051$. [CrossRef] 
33. Demirbas, A.; Rector, B.G.; Lohnes, D.G.; Fioritto, R.J.; Graef, G.L.; Cregan, P.B.; Shoemaker, R.C.; Specht, J.E. Cell Biology \& Molecular Genetics Simple Sequence Repeat Markers Linked to the Soybean Rps Genes for Phytophthora Resistance. Crop Sci. 2001, 41, 1220-1227.

34. Wu, X.L.; Zhang, B.Q.; Sun, S.; Zhao, J.M.; Yang, F.; Guo, N.; Gai, J.Y.; Xing, H. Identification, Genetic Analysis and Mapping of Resistance to Phytophthora Sojae of Pm28 in Soybean. Agric. Sci. China 2011, 10, 1506-1511. [CrossRef]

35. Li, Y.; Sun, S.; Chao., Z.; Wang, X.; Wu, X.; Zhu, Z. Genetic Mapping and Development of Co-Segregating Markers of RpsQ, Which Provides Resistance to Phytophthora sojae in Soybean. Theor. Appl. Genet. 2017, 130, 1223-1233. [CrossRef] [PubMed]

36. Lin, F.; Zhao, M.; Ping, J.; Johnson, A.; Zhang, B.; Scott, A.T.; Hughes, T.J.; Ma, J. Molecular Mapping of Two Genes Conferring Resistance to Phytophthora sojae in a Soybean Landrace PI 567139B. Theor. Appl. Genet. 2013, 126, 2177-2185. [CrossRef] [PubMed]

37. Batley, J.; McHale, L.; Gijzen, M.; Xing, H.; Zhao, T.; Niu, J.; Guo, N.; Sun, J.; Li, L.; Cao, Y.; et al. Fine Mapping of a Resistance Gene RpsHN That Controls Phytophthora sojae Using Recombinant Inbred Lines and Secondary Populations. Front. Plant Sci. 2017, 8, 538. [CrossRef]

38. Sugimoto, T.; Yoshida, S.; Watanabe, K.; Aino, M.; Kanto, T.; Maekawa, K.; Irie, K. Identification of SSR Markers Linked to the Phytophthora Resistance Gene Rps1-d in Soybean. Plant Breed. 2008, 127, 154-159. [CrossRef]

39. Sugimoto, T.; Yoshida, S.; Kaga, A.; Hajika, M.; Watanabe, K.; Aino, M.; Tatsuda, K.; Yamamoto, R.; Matoh, T.; Walker, D.R.; et al. Genetic Analysis and Identification of DNA Markers Linked to a Novel Phytophthora sojae Resistance Gene in the Japanese Soybean Cultivar Waseshiroge. Euphytica 2011, 182, 133-145. [CrossRef]

40. Sun, S.; Wu, X.L.; Zhao, J.M.; Wang, Y.C.; Tang, Q.H.; Yu, D.Y.; Gai, J.Y.; Xing, H. Characterization and Mapping of RpsYu25, a Novel Resistance Gene to Phytophthora sojae. Plant Breed. 2011, 130, 139-143. [CrossRef]

41. Zhong, C.; Li, Y.; Sun, S.; Duan, C.; Zhu, Z. Genetic Mapping and Molecular Characterization of a Broad-Spectrum Phytophthora sojae Resistance Gene in Chinese Soybean. Int. J. Mol. Sci. 2019, 20, 1809. [CrossRef]

42. Weng, C.; Yu, K.; Anderson, T.R.; Poysa, V. Mapping Genes Conferring Resistance to Phytophthora Root Rot of Soybean, Rps1a and Rps7. J. Hered. 2001, 92, 442-446. [CrossRef]

43. Kaitany, R.C.; Hart, L.P.; Safir, G.R. Virulence Composition of Phytophthora sojae in Michigan. Plant Dis. 2001, 85, 1103-1106. [CrossRef]

44. Dorrance, A.E.; McClure, S.A.; DeSilva, A. Pathogenic Diversity of Phytophthora sojae in Ohio Soybean Fields. Plant Dis. 2003, 87, 139-146. [CrossRef]

45. Costamilan, L.M.; Clebsch, C.C.; Soares, R.M.; Seixas, C.D.S.; Godoy, C.V.; Dorrance, A.E. Pathogenic Diversity of Phytophthora sojae Pathotypes from Brazil. Eur. J. Plant Pathol. 2013, 135, 845-853. [CrossRef]

46. Ye, W.; Wang, X.; Tao, K.; Lu, Y.; Dai, T.; Dong, S.; Dou, D.; Gijzen, M.; Wang, Y. Digital Gene Expression Profiling of the Phytophthora sojae Transcriptome. Mol. Plant-Microbe Interact. 2011, 24, 1530-1539. [CrossRef] [PubMed]

47. Chen, X.; Shen, G.; Wang, Y.; Zheng, X.; Wang, Y. Identification of Phytophthora sojae Genes Upregulated during the Early Stage of Soybean Infection. FEMS Microbiol. Lett. 2007, 269, 280-288. [CrossRef] [PubMed]

48. Liu, T.; Ye, W.; Ru, Y.; Yang, X.; Gu, B.; Tao, K.; Lu, S.; Dong, S.; Zheng, X.; Shan, W.; et al. Two Host Cytoplasmic Effectors Are Required for Pathogenesis of Phytophthora sojae by Suppression of Host Defenses. Plant Physiol. 2011, 155, 490-501. [CrossRef] [PubMed]

49. Zhang, M.; Li, Q.; Liu, T.; Liu, L.; Shen, D.; Zhu, Y.; Liu, P.; Zhou, J.-M.; Dou, D. Two Cytoplasmic Effectors of Phytophthora sojae Regulate Plant Cell Death via Interactions with Plant Catalases. Plant Physiol. 2015, 167, 164-175. [CrossRef]

50. Rajput, N.A.; Zhang, M.; Ru, Y.; Liu, T.; Xu, J.; Liu, L.; Mafurah, J.J.; Dou, D. Phytophthora sojae Effector PsCRN70 Suppresses Plant Defenses in Nicotiana Benthamiana. PLoS ONE 2014, 9, e98114. [CrossRef]

51. Wang, Y.; Wang, Y. Phytophthora sojae Effectors Orchestrate Warfare with Host Immunity. Curr. Opin. Microbiol. 2018, 46, 7-13. [CrossRef]

52. Dong, S.; Kong, G.; Qutob, D.; Yu, X.; Tang, J.; Kang, J.; Dai, T.; Wang, H.; Gijzen, M.; Wang, Y. The NLP Toxin Family in Phytophthora sojae Includes Rapidly Evolving Groups That Lack Necrosis-Inducing Activity. Mol. Plant-Microbe Interact. 2012, 25, 896-909. [CrossRef]

53. Ma, Z.; Song, T.; Zhu, L.; Ye, W.; Wang, Y.; Shao, Y.; Dong, S.; Zhang, Z.; Dou, D.; Zheng, X.; et al. A Phytophthora sojae Glycoside Hydrolase 12 Protein Is a Major Virulence Factor during Soybean Infection and Is Recognized as a PAMP. Plant Cell 2015, 27, 2057-2072. [CrossRef]

54. Ma, Z.; Zhu, L.; Song, T.; Wang, Y.; Zhang, Q.; Xia, Y.; Qiu, M.; Lin, Y.; Li, H.; Kong, L.; et al. A Paralogous Decoy Protects Phytophthora sojae Apoplastic Effector PsXEG1 from a Host Inhibitor. Science 2017, 355, 710-714. [CrossRef]

55. Ai, G.; Xia, Q.; Song, T.; Li, T.; Zhu, H.; Peng, H.; Liu, J.; Fu, X.; Zhang, M.; Jing, M.; et al. A Phytophthora sojae CRN Effector Mediates Phosphorylation and Degradation of Plant Aquaporin Proteins to Suppress Host Immune Signaling. PLoS Pathog. 2021, 17, e1009388. [CrossRef] [PubMed]

56. Song, T.; Ma, Z.; Shen, D.; Li, Q.; Li, W.; Su, L.; Ye, T.; Zhang, M.; Wang, Y.; Dou, D. An Oomycete CRN Effector Reprograms Expression of Plant HSP Genes by Targeting Their Promoters. PLoS Pathog. 2015, 11, e1005348. [CrossRef] [PubMed]

57. Liu, T.; Song, T.; Zhang, X.; Yuan, H.; Su, L.; Li, W.; Xu, J.; Liu, S.; Chen, L.; Chen, T.; et al. Unconventionally Secreted Effectors of Two Filamentous Pathogens Target Plant Salicylate Biosynthesis. Nat. Commun. 2014, 5, 4686. [CrossRef] [PubMed]

58. Fang, Y.; Cui, L.; Gu, B.; Arredondo, F.; Tyler, B.M. Efficient Genome Editing in the Oomycete Phytophthora sojae Using CRISPR/Cas9. Curr. Protoc. Microbiol. 2017, 44, 21A.1.1-21A.1.26. [CrossRef] 
59. Liu, D.; Li, K.; Hu, J.; Li, P.; Liu, X.; Gao, Z. PsGRGH, a TOS1 Family-like Gene, Is Involved in the Vegetative Growth, Environmental Stress Response, and Pathogenicity of Phytophthora sojae. Eur. J. Plant Pathol. 2021, 160, 67-79. [CrossRef]

60. Zhou, L.; Mideros, S.X.; Bao, L.; Hanlon, R.; Arredondo, F.D.; Tripathy, S.; Krampis, K.; Jerauld, A.; Evans, C.; St Martin, S.K.; et al. Infection and Genotype Remodel the Entire Soybean Transcriptome. BMC Genom. 2009, 10, 49. [CrossRef]

61. Lin, F.; Zhao, M.; Baumann, D.D.; Ping, J.; Sun, L.; Liu, Y.; Zhang, B.; Tang, Z.; Hughes, E.; Doerge, R.W.; et al. Molecular Response to the Pathogen Phytophthora sojae among Ten Soybean near Isogenic Lines Revealed by Comparative Transcriptomics. BMC Genom. 2014, 15, 18. [CrossRef]

62. Moy, P.; Qutob, D.; Chapman, B.P.; Atkinson, I.; Gijzen, M. Patterns of Gene Expression upon Infection of Soybean Plants by Phytophthora sojae. Mol. Plant-Microbe Interact. 2004, 17, 1051-1062. [CrossRef]

63. Guo, N.; Ye, W.-W.; Wu, X.-L.; Shen, D.-Y.; Wang, Y.-C.; Xing, H.; Dou, D.-L.; Donini, P. Microarray Profiling Reveals MicroRNAs Involving Soybean Resistance to Phytophthora sojae. Genome 2011, 54, 954-958. [CrossRef]

64. Xu, P.F.; Wu, J.J.; Xue, A.; Li, W.B.; Chen, W.Y.; Wei, L.; Lv, H.Y.; Lin, S.F.; Fan, S.J.; Li, N.H.; et al. Differentially Expressed Genes of Soybean During Infection by Phytophthora sojae. J. Integr. Agric. 2012, 11, 368-377. [CrossRef]

65. Narayanan, N.N.; Grosic, S.; Tasma, I.M.; Grant, D.; Shoemaker, R.; Bhattacharyya, M.K. Identification of Candidate Signaling Genes Including Regulators of Chromosome Condensation 1 Protein Family Differentially Expressed in the Soybean-Phytophthora sojae Interaction. Theor. Appl. Genet. 2009, 118, 399-412. [CrossRef] [PubMed]

66. Xu, P.; Jiang, L.; Wu, J.; Li, W.; Fan, S.; Zhang, S. Isolation and Characterization of a Pathogenesis-Related Protein 10 Gene (GmPR10) with Induced Expression in Soybean (Glycine max) during Infection with Phytophthora sojae. Mol. Biol. Rep. 2014, 41, 4899-4909. [CrossRef] [PubMed]

67. Jiang, L.; Wu, J.; Fan, S.; Li, W.; Dong, L.; Cheng, Q.; Xu, P.; Zhang, S. Isolation and Characterization of a Novel PathogenesisRelated Protein Gene (GmPRP) with Induced Expression in Soybean (Glycine max) during Infection with Phytophthora sojae. PLoS ONE 2015, 10, e0129932. [CrossRef] [PubMed]

68. Cheng, Q.; Li, N.; Dong, L.; Zhang, D.; Fan, S.; Jiang, L.; Wang, X.; Xu, P.; Zhang, S. Overexpression of Soybean Isoflavone Reductase (GmIFR) Enhances Resistance to Phytophthora sojae in Soybean. Front. Plant Sci. 2015, 6, 1024. [CrossRef]

69. Chen, Q.S.; Yu, G.L.; Zou, J.N.; Wang, J.; Qiu, H.M.; Zhu, R.S.; Chang, H.L.; Jiang, H.W.; Hu, Z.B.; Li, C.Y.; et al. GmDRR1, a Dirigent Protein Resistant to Phytophthora sojae in Glycine max (L.) Merr. J. Integr. Agric. 2018, 17, 1289-1298. [CrossRef]

70. Fan, S.; Dong, L.; Han, D.; Zhang, F.; Wu, J.; Jiang, L.; Cheng, Q.; Li, R.; Lu, W.; Meng, F.; et al. GmWRKY31 and GmHDL56 Enhances Resistance to Phytophthora sojae by Regulating Defense-Related Gene Expression in Soybean. Front. Plant Sci. 2017, 8, 781. [CrossRef]

71. Cui, X.; Yan, Q.; Gan, S.; Xue, D.; Wang, H.; Xing, H.; Zhao, J.; Guo, N. GmWRKY40, a Member of the WRKY Transcription Factor Genes Identified from Glycine max L., Enhanced the Resistance to Phytophthora sojae. BMC Plant Biol. 2019, 19, 598. [CrossRef]

72. Zhou, Y.; Huang, J.L.; Zhang, X.L.; Zhu, L.M.; Wang, X.F.; Guo, N.; Zhao, J.M.; Xing, H. Overexpression of Chalcone Isomerase (CHI) Increases Resistance Against Phytophthora sojae in Soybean. J. Plant Biol. 2018, 61, 309-319. [CrossRef]

73. Jing, M.; Ma, H.; Li, H.; Guo, B.; Zhang, X.; Ye, W.; Wang, H.; Wang, Q.; Wang, Y. Differential Regulation of Defense-Related Proteins in Soybean during Compatible and Incompatible Interactions between Phytophthora sojae and Soybean by Comparative Proteomic Analysis. Plant Cell Rep. 2015, 34, 1263-1280. [CrossRef]

74. Zhang, Y.M.; Zhao, J.M.; Xiang, Y.; Bian, X.C.; Zuo, Q.M.; Shen, Q.; Gai, J.Y.; Xing, H. Proteomics Study of Changes in Soybean Lines Resistant and Sensitive to Phytophthora sojae. Proteome Sci. 2011, 9, 52. [CrossRef]

75. Wang, X.; Zhao, Z.; Guo, N.; Wang, H.; Zhao, J.; Xing, H. Comparative Proteomics Analysis Reveals That Lignin Biosynthesis Contributes to Brassinosteroid-Mediated Response to Phytophthora sojae in Soybeans. J. Agric. Food Chem. 2020, 68, 5496-5506. [CrossRef] [PubMed]

76. Stasko, A.K.; Batnini, A.; Bolanos-Carriel, C.; Lin, J.E.; Lin, Y.; Blakeslee, J.J.; Dorrance, A.E. Auxin Profiling and GmPIN Expression in Phytophthora sojae soybean Root Interactions. Phytopathology 2020, 110, 1988-2002. [CrossRef] [PubMed]

77. Zhu, L.; Zhou, Y.; Li, X.; Zhao, J.; Guo, N.; Xing, H. Metabolomics Analysis of Soybean Hypocotyls in Response to Phytophthora sojae Infection. Front. Plant Sci. 2018, 9, 1530. [CrossRef] [PubMed]

78. Zehra, A.; Raytekar, N.A.; Meena, M.; Swapnil, P. Efficiency of Microbial Bio-Agents as Elicitors in Plant Defense Mechanism under Biotic Stress: A Review. In Current Research in Microbial Sciences; Elsevier Ltd.: Amsterdam, The Netherlands, 2021. [CrossRef]

79. Siah, A.; Magnin-Robert, M.; Randoux, B.; Choma, C.; Rivière, C.; Halama, P.; Reignault, P.; Siah, A.; Choma, Á.C.; Halama, Á.P.; et al. Natural Agents Inducing Plant Resistance Against Pests and Diseases; Springer: Cham, Switzerland, 2018 ; Volume 19. [CrossRef]

80. Sahoo, D.K.; Abeysekara, N.S.; Cianzio, S.R.; Robertson, A.E.; Bhattacharyya, M.K. A Novel Phytophthora sojae Resistance Rps12 Gene Mapped to a Genomic Region That Contains Several Rps Genes. PLoS ONE 2017, 12, e0169950. [CrossRef] [PubMed]

81. Harlan, H.V.; Pope, M.N. The Use and Value of Back-Crosses in Small-Grain Breeding. J. Hered. 1922, 13, 319-322. [CrossRef]

82. Schmutz, J.; Cannon, S.B.; Schlueter, J.; Ma, J.; Mitros, T.; Nelson, W.; Hyten, D.L.; Song, Q.; Thelen, J.J.; Cheng, J.; et al. Genome Sequence of the Palaeopolyploid Soybean. Nature 2010, 463, 178-183. [CrossRef]

83. Polzin, K.M.; Lohnes, D.G.; Nickell, C.D.; Shoemaker, R.C. Integration of Rps2, Rmd, and Rj2 Into Linkage Group J of the Soybean Molecular Map. J. Hered. 1994, 85, 300-303. [CrossRef] 
84. Na, R.; Gijzen, M. Escaping Host Immunity: New Tricks for Plant Pathogens. PLoS Pathog. 2016, 12, e1005631. [CrossRef] [PubMed]

85. Rolando, C.A.; Dick, M.A.; Gardner, J.; Bader, M.K.F.; Williams, N.M. Chemical Control of Two Phytophthora Species Infecting the Canopy of Monterey Pine (Pinus radiata). For. Pathol. 2017, 47, e12327. [CrossRef]

86. Colburn, G.C.; Jeffers, S.N. Efficacy of Commercial Algaecides to Manage Species of Phytophthora in Suburban Waterways; Frankel, S.J., Kliejunas, J.T., Palmieri, K.M., Eds.; Proceedings of the Sudden Oak Death Fourth Science Symposium: Gen. Tech. Rep. PSW-GTR-229; US Department of Agriculture, Forest Service, Pacific Southwest Research Station: Albany, CA, USA, 2010.

87. Zhen-Dong, Z.; Xiao-Ming, W.; Yu-Lan, T.; Xiao-Fei, W. Screening of Fungicides for Controlling Phytophthora Root Rot of Soybean. Chin. J. Pestic. Sci. 1999, 1, 39-44.

88. Dorrance, A.E.; Robertson, A.E.; Cianzo, S.; Giesler, L.J.; Grau, C.R.; Draper, M.A.; Tenuta, A.U.; Anderson, T.R. Integrated Management Strategies for Phytophthora sojae Combining Host Resistance and Seed Treatments. Plant Dis. $2009,93,875-882$. [CrossRef] [PubMed]

89. Schmitthenner, A.F. Phytophthora Rot of Soybean. Plant Health Prog. 2000, 1, 13. [CrossRef]

90. Triplett, G.B.; Dick, W.A. No-Tillage Crop Production: A Revolution in Agriculture! Agron. J. 2008, 100, S-153. [CrossRef]

91. Workneh, F.; Yang, X.B.; Tylka, G.L. Effect of Tillage Practices on Vertical Distribution of Phytophthora sojae. Plant Dis. 1998, 82, 1258-1263. [CrossRef] [PubMed]

92. Canaday, C.H.; Schmitthenner, A.F. Effects of Chloride and Ammonium Salts on the Incidence of Phytophthora Root and Stem Rot of Soybean. Plant Dis. 2010, 94, 758-765. [CrossRef] [PubMed]

93. Zhao, L.-M.; Shuang, L.; Sui, Z.; Huang, J.; Chen, Q.M.; Suo, B.; Ding, J.-J.; Liu, W.-T.; Wen, J.-Z. Impact of Crop Rotation on Pathotype and Genetic Structure of Phythophthora Sojae in Fields. J. Northeast Agric. Univ. 2016, 23, 1-12. [CrossRef]

94. Zhang, H.; Yang, Y.; Mei, X.; Li, Y.; Wu, J.; Li, Y.; Wang, H.; Huang, H.; Yang, M.; He, X.; et al. Phenolic Acids Released in Maize Rhizosphere During Maize-Soybean Intercropping Inhibit Phytophthora Blight of Soybean. Front. Plant Sci. 2020, 11, 886. [CrossRef]

95. Ciancio, A.; Mukerji, K.G. General Concepts in Integrated Pest and Disease Management; Ciancio, A., Mukerji, K.G., Eds.; Springer: New York, NY, USA, 2007.

96. Declerck, S.; Willems, A.; van der Heijden, M.G.A.; Varese, G.C.; Turkovskaya, O.; Evtushenko, L.; Ivshina, I.; Desmeth, P. PERN: An EU-Russia Initiative for Rhizosphere Microbial Resources. Trends Biotechnol. 2015, 33, 377-380. [CrossRef]

97. Bolívar-Anillo, H.J.; Garrido, C.; Collado, I.G. Endophytic Microorganisms for Biocontrol of the Phytopathogenic Fungus Botrytis Cinerea. Phytochem. Rev. 2020, 19, 721-740. [CrossRef]

98. Naik, K.; Mishra, S.; Srichandan, H.; Singh, P.K.; Sarangi, P.K. Plant Growth Promoting Microbes: Potential Link to Sustainable Agriculture and Environment. Biocatal. Agric. Biotechnol. 2019, 21, 101326. [CrossRef]

99. Arfaoui, A.; Adam, L.R.; Bezzahou, A.; Daayf, F. Isolation and Identification of Cultivated Bacteria Associated with Soybeans and Their Biocontrol Activity against Phytophthora sojae. BioControl 2018, 63, 607-617. [CrossRef]

100. Arfaoui, A.; El Hadrami, A.; Adam, L.R.; Daayf, F. Combining Streptomyces Hygroscopicus and Phosphite Boosts Soybean's Defense Responses to Phytophthora sojae. BioControl 2020, 65, 363-375. [CrossRef]

101. Dowarah, B.; Gill, S.S.; Agarwala, N. Arbuscular Mycorrhizal Fungi in Conferring Tolerance to Biotic Stresses in Plants. J. Plant Growth Regul. 2021. [CrossRef]

102. Giachero, M.L.; Marquez, N.; Gallou, A.; Luna, C.M.; Declerck, S.; Ducasse, D.A. An In Vitro Method for Studying the Three-Way Interaction between Soybean, Rhizophagus Irregularis and the Soil-Borne Pathogen Fusarium Virguliforme. Front. Plant Sci. 2017, 8, 1033. [CrossRef]

103. Marquez, N.; Giachero, M.L.; Gallou, A.; Debat, H.J.; Cranenbrouck, S.; Di Rienzo, J.A.; Pozo, M.J.; Ducasse, D.A.; Declerck, S. Transcriptional Changes in Mycorrhizal and Nonmycorrhizal Soybean Plants upon Infection with the Fungal Pathogen Macrophomina phaseolina. Mol. Plant-Microbe Interact. 2018, 31, 842-855. [CrossRef] [PubMed]

104. Marquez, N.; Giachero, M.L.; Gallou, A.; Debat, H.J.; Declerck, S.; Ducasse, D.A. Transcriptome Analysis of Mycorrhizal and Nonmycorrhizal Soybean Plantlets upon Infection with Fusarium Virguliforme, One Causal Agent of Sudden Death Syndrome. Plant Pathol. 2019, 68, 470-480. [CrossRef]

105. Li, Y.; Liu, Z.; Hou, H.; Lei, H.; Zhu, X.; Li, X.; He, X.; Tian, C. Arbuscular Mycorrhizal Fungi-Enhanced Resistance against Phytophthora sojae Infection on Soybean Leaves Is Mediated by a Network Involving Hydrogen Peroxide, Jasmonic Acid, and the Metabolism of Carbon and Nitrogen. Acta Physiol. Plant. 2013, 35, 3465-3475. [CrossRef]

106. Jog, R.; Pandya, M.; Nareshkumar, G.; Rajkumar, S. Mechanism of Phosphate Solubilization and Antifungal Activity of Streptomyces Spp. Isolated from Wheat Roots and Rhizosphere and Their Application in Improving Plant Growth. Microbiology 2014, 160, 778-788. [CrossRef]

107. Arshad Ali, M.; Lou, Y.; Hafeez, R.; Li, X.; Hossain, A.; Xie, T.; Lin, L.; Li, B.; Yin, Y. Functional Analysis and Genome Mining Reveal High Potential of Biocontrol and Plant Growth Promotion in Nodule-Inhabiting Bacteria Within Paenibacillus polymyxa Complex. Front. Microbiol. 2021, 11, 618601. [CrossRef]

108. Wagner, A.; Norris, S.; Chatterjee, P.; Morris, P.F.; Wildschutte, H. Aquatic Pseudomonads Inhibit Oomycete Plant Pathogens of Glycine max. Front. Microbiol. 2018, 9, 1007. [CrossRef]

109. Hou, J.; Bi, S.; Yan, L.; Zuo, Y.; Wang, Y.; Liu, T.; Zhu, J. Biological Potential of Pseudomonas Sp. BS1 in the Control of Phytophthora Root Rot of Soybean. Afr. J. Microbiol. Res. 2012, 6, 3589-3593. [CrossRef] 
110. Zhao, L.F.; Xu, Y.J.; Lai, X.H. Antagonistic Endophytic Bacteria Associated with Nodules of Soybean (Glycine max L.) and Plant Growth-Promoting Properties. Braz. J. Microbiol. 2018, 49, 269-278. [CrossRef] [PubMed]

111. Harman, G.E.; Howell, C.R.; Viterbo, A.; Chet, I.; Lorito, M. Trichoderma Species-Opportunistic, Avirulent Plant Symbionts. Nat. Rev. Microbiol. 2004, 2, 43-56. [CrossRef] [PubMed]

112. Ayoubi, N.; Zafari, D.; Mirabolfathy, M. Combination of Trichoderma Species and Bradyrhizobium Japonicum in Control of Phytophthora sojae and Soybean Growth. J. Crop Prot. 2012, 1, 67-79.

113. Xi, X.; Fan, J.; Yang, X.; Liang, Y.; Zhao, X.; Wu, Y. Evaluation of the Anti-Oomycete Bioactivity of Rhizosphere Soil-Borne Isolates and the Biocontrol of Soybean Root Rot Caused by Phytophthora sojae. Biol. Control 2022, 166, 104818. [CrossRef]

114. Sacristan, S.; Goss, E.M.; Eves-Van Den Akker, S. How Do Pathogens Evolve Novel Virulence Activities? In Molecular Plant-Microbe Interactions; American Phytopathological Society: Saint Paul, MN, USA, 2021. [CrossRef] 